\title{
Postoje žáků k řešení slovních úloh
}

\section{Pupil's attitudes towards problem solving}

\author{
Alena Rakoušová
}

\begin{abstract}
Abstrakt: Př́spěvek se zaměřuje na realizaci šetření, které se týkalo způsobů zařazování integrovaných slovních úloh do výuky. Popisuje vliv jejich zařazování na postoje žáků 1. stupně základní školy k řešení slovních úloh. Byly použity následující metodologie: Metoda nedokončených vět, sémantický diferenciál, analýza žákovského řešení slovních úloh. Výsledkem je zjištění vlivu zařazování integrovaných slovních úloh do výuky na postoje žáků $\mathrm{k}$ řešení slovních úloh.
\end{abstract}

Klíčová slova: integrované slovní úlohy, postoje žáků k řešení slovních úloh.

Abstract: The paper focuses on inclusion of integrated word problems into mathematics lessons at the primary level. Their influence on pupil's attitudes towards problem solving is analyzed. Semantic differential and method of unfinished sentences were used.

Keywords: integrated word problems, pupil's attitudes towards problem solving

\section{1 Úvod}

Příspěvek je věnován otázce, jaký vliv na postoje žáků k řešení slovních úloh má zařazování integrovaných slovních úloh do vyučování žáků 1 . stupně základní školy. Žáci (nejen) na 1. stupni ZŠ považují často slovní úlohy za obtížné a jejich postoje $\mathrm{k}$ nim jsou v mnoha př́padech negativní (Novotná, 2000). Ačkoliv je význam slovních úloh pro rozvoj porozumění matematice a jejich využití mimo vyučování matematice nesporný (Novotná, 2010), nepodařilo se prozatím najít žádnou univerzální metodu, kterou by bylo možno tyto postoje upravit. Př́spěvek seznamuje s integrovanými slovními úlohami a věnuje pozornost vlivu těchto úloh na postoje žáků k řešení slovních úloh. Řešení slovních úloh je žáky základní školy považováno za obtížné, a jak dosavadní výzkumy prokázaly (Novotná, 2010), postoje žáků k řešení slovních úloh jsou často negativní. V pedagogické práci na základní škole a ve výzkumu se věnujeme zařazování tzv. integrovaných slovních úloh (ISU) do vyučování a zajímá nás především vliv různých způsobů zařazování těchto úloh na změny postojů žáků 1. stupně základního vzdělávání k řešení slovních úloh.

\subsection{Vymezení pojmů}

Integrovanou slovní úlohu lze vymezit jako úlohu, která propojuje cíle a výsledky různých vyučovacích předmětů v jeden - integrovaný - cíl. Jako taková je pomocí v práci učitele s obsahem, je nástrojem propojení obsahu prostřednictvím společného tématu (viz obrázek 1). 


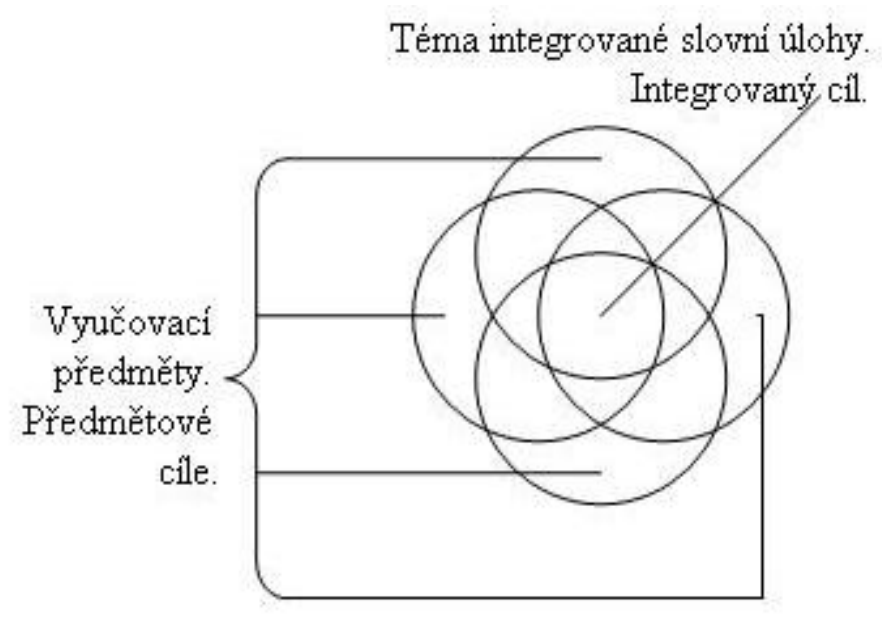

Obrázek 1. Schéma integrované slovní úlohy

K integraci v tomto přípaě dochází na základě vzájemného pronikání cílů vyučovacích předmětů do nějakého tématu tam, kde je to smysluplné v rámci předmětového kurikula. Dosavadní stav problematiky integrace tématu prostřednictvím slovní úlohy na 1. stupni základní školy není uspokojivý. Je to logické, protože integrace jako taková byla od konce 30. let až do roku 1989 pokládána za nepríípustnou. To, aby úloha spojovala více cílů do té doby separovaných předmětů, nebylo vůbec myslitelné a metodiky předmětů 1. stupně ZŠ byly př́sně normativní. Žádný z učitelů nemohl učit, jak by chtěl, vzdělávací obsah byl přesně naplánován a s koordinací učiva matematiky s ostatními vyučovacími předměty nepočítal. Hovoříme-li o koordinaci cílů úlohy, nemáme na mysli mezipředmětové vazby, protože $\mathrm{v}$ prrípadě integrace se žák naučí něco nového $\mathrm{z}$ různých předmětů, kdežto $\mathrm{v}$ rámci mezipředmětových aktivit pouze využívá to, co už před tím z různých předmětů věděl. Metodika ISU je vhodná pro české žáky, protože respektuje české podmínky i dosavadní vývoj didaktického myšlení.

\subsection{Postup výzkumu}

V rámci předvýzkumu, který probíhal v letech 2009-2011, jsme si pokládali otázku, zda je postoj žáků $\mathrm{k}$ řešení slovních úloh ovlivňován uspořádáním obsahu. V průběhu dvou let jsme provedli dva experimenty. V prvním roce (2009-2010) jsme žákům předkládali řadu integrovaných slovních úloh pouze v hodinách matematiky. Protože úloha integrovala cíle některých dalších vyučovacích předmětů a tyto předměty tudíž pronikaly do hodin matematiky, kompenzovali jsme čas věnovaný těmto předmětům tak, že jsme naopak několik matematických úkolů integrovali do ostatních předmětů. Ve výzkumu jsme se soustředili na to, zda došlo ke zlepšení postojủ žáků k řešení slovních úloh po zařazování ISU do hodin matematiky po dobu jednoho školního roku.

Druhý experiment jsme provedli v roce 2010-2011, kdy vyučující (autorka přípěvku) předkládala žákům ISU $\mathrm{k}$ řešení nejen $\mathrm{v}$ matematice, ale $\mathrm{i} v$ ostatních vyučovacích předmětech průřezově - aniž by výuka ISU byla omezena pouze na hodiny matematiky a aniž by matematika byla kompenzována $\mathrm{v}$ ostatních předmětech činností, která $\mathrm{s}$ ISU nesouvisí. Cílem bylo zjistit, zda zařazování ISU v rámci tematických celků do hodin matematiky i do hodin ostatních vyučovacích předmětů zlepšuje postoje žáků k řešení slovních úloh. Do roku 2009 se žáci daného vzorku s ISU nesetkali.

Třetí experiment jsme zaměřili na zjištění rozdílu mezi stávající skupinou experimentální a další skupinou - kontrolní. Cílem bylo zjištění statistické významnosti rozdílu mezi oběma skupinami. 


\subsection{Hypotézy}

Hlavní hypotézy:

H I Zařazování integrovaných slovních úloh v rámci vyučovacích hodin matematiky zlepšuje postoje žáků k řešení slovních úloh.

H II Zařazování integrovaných slovních úloh v rámci tematických celků v matematice a ostatních vyučovacích předmětech zlepšuje postoje žáků k řešení slovních úloh.

H III Integrované slovní úlohy významně zlepšují postoje k řešení slovních úloh.

Dílčí hypotézy:

$\mathrm{h}_{0}$ Mezi výsledky získanými sémantickým diferenciálem na výstupu experimentu $\mathrm{v}$ obou skupinách nejsou rozdíly.

$\mathrm{h}_{\mathrm{A}}$ Mezi výsledky získanými sémantickým diferenciálem na výstupu experimentu vobou skupinách žáků jsou významné rozdíly.

\subsection{Výzkumný vzorek}

První dva experimenty byly uskutečněny na vzorku 23 žáků jedné třídy základní školy. První experiment byl realizován v rámci 3. ročníku, druhý experiment pak ve 4. ročníku. Ve třetím experimentu byl 4. ročník experimentální skupinou, vzorek byl rozšířen o dvě paralelní třídy 4. ročníku $(22+23$ žáci). Tyto trrídy tvořily kontrolní skupinu. Celkem se experimentu zúčastnilo 68 žáků. Fáze předvýzkumu shrnuje tabulka 1.

Tabulka 1

Fáze předvýzkumu

\begin{tabular}{|c|c|c|c|c|c|c|}
\hline Měření & \multicolumn{2}{|c|}{ Pořadí experimentů } & $\begin{array}{l}\text { Nezávisle } \\
\text { proměnná }\end{array}$ & $\begin{array}{l}\text { Závisle } \\
\text { proměnná }\end{array}$ & \multicolumn{2}{|c|}{ Výzkumný vzorek } \\
\hline $\begin{array}{l}\text { Září } \\
2009\end{array}$ & \multicolumn{2}{|c|}{ 1. experiment } & $\begin{array}{l}\text { Zařazování } \\
\text { integrovaných } \\
\text { slovních úloh } \\
\text { pouze do } \\
\text { hodin } \\
\text { matematiky }\end{array}$ & \multirow{3}{*}{$\begin{array}{l}\text { Postoje } \\
\text { k řešení } \\
\text { slovních } \\
\text { úloh }\end{array}$} & \multicolumn{2}{|c|}{ 3. ročník (2009-2010) } \\
\hline $\begin{array}{c}\text { Červen } \\
2010\end{array}$ & $\downarrow$ & & & & & \\
\hline $\begin{array}{c}\text { Červen } \\
2011\end{array}$ & $\begin{array}{c}2 . \\
\text { experiment }\end{array}$ & $\begin{array}{c}3 . \\
\text { experiment }\end{array}$ & $\begin{array}{c}\text { Zařazování } \\
\text { integrovaných } \\
\text { slovních úloh } \\
\text { např́ič } \\
\text { vyučovacími } \\
\text { předměty }\end{array}$ & & $\begin{array}{c}\text { 4. ročník } \\
\text { (2010-2011) } \\
\text { Experimentální } \\
\text { skupina }\end{array}$ & $\begin{array}{l}\text { 4. ročník } \\
\text { (2010-2011) } \\
\text { Experimentální } \\
\text { a kontrolní } \\
\text { skupina }\end{array}$ \\
\hline
\end{tabular}

Experimentální skupině byla po dobu 2 let školní docházky předkládána řada ISU a řada tradičních slovních úloh z učebnice Prodos pro 3. a pro 4. ročník. Kontrolní skupina prošla výukou matematiky podle učebnice Prodos pro 3. a pro 4. ročník a nebyla výukou ISU ovlivněna.

Míru obecnější platnosti lze i v tomto případě odhadovat, i když ne validně prokázat. $Z$ tohoto důvodu počítáme s uvedeným experimentem jako se součástí většího výzkumu, v jehož rámci bude do náhodného výběru zahrnut větší počet žáků. 


\subsection{Metodologie}

Kvalitativní stránku výzkumu jsme zajistili metodou nedokončených vět (podrobnější analýzu naleznou čtenáři v Rakoušová, 2011), kvantitativní pak metodou sémantického diferenciálu.

- Metoda nedokončených vět

Žákům bylo předloženo 5 nedokončených vět, které měli dokončit první smysluplnou myšlenkou. (Podle Pelikán, 1998.)

- Sémantický diferenciál

Smyslem metody sémantického diferenciálu je změřit a rozlišit postoje $\mathrm{k}$ řešení slovních úloh mezi jednotlivými žáky. Jejím autorem je americký profesor C. Osgood (1957). Každý žák přičítá pojmům různé významy. Tyto významy byly měřeny pomocí sedmibodových posuzovacích škál. Žáci $\mathrm{v}$ roli respondentů zaznamenali svoje mínění o slovních úlohách výběrem bodu na škále. Každá škála je ohraničena dvojicí protikladných adjektiv. Záznamem na škále žáci vyjádřili v podstatě míru vlastnosti, kterou úlohám přrisuzovali.

Každý pojem lze posuzovat podle tří faktorů: faktor hodnocení, faktor potence a faktor aktivity. Faktor hodnocení lze hodnotit jako dobro x zlo, faktor potence je hodnocen $\mathrm{z}$ hlediska síly slovních úloh (zda úlohám žák připisuje např. obtížnost nebo nikoli, zda je vnímá jako propojené se školním či mimoškolním životem) a faktor aktivity hodnotíme jako vztah k pohybu a změnám (srov. Chráska 2007, s. 221). Tř́i škály byly prezentovány v reverzní podobě z toho důvodu, aby se snížilo nebezpečí stereotypního posuzování ve škálách. U těchto škál byly převráceny krajní body. (Tamtéž.) Jednotlivým bodům na škále byly přiřazeny číselné hodnoty v rozpětí 1-7.

\subsection{Analýza dat}

- Metoda nedokončených vět

Dokončené věty byly vyhodnoceny kategorizací do tř́ skupin. K dokončeným větám byly přiřazeny hodnoty: pozitivní kategorie $(+1)$, neutrální $(0)$, negativní $(-1)$. Na výstupu došlo $\mathrm{k}$ výraznému navýšení kladného bodového zisku. V tabulce 2 vidíme index postojů, který byl stanovený výpočtem rozdílu průměrů kladných a záporných bodů na vstupu i na výstupu. Rozdíly v kladně a záporně zabarvených výrocích jsou výrazné.

Tabulka 2

Index postojů ke slovním úlohám

\begin{tabular}{|c|c|c|}
\hline \multicolumn{2}{|c|}{$\begin{array}{c}\text { Rozdíl v průměrných hodnotách kladných a } \\
\text { záporných bodù získaných kvalitativním } \\
\text { šetřením - metodou nedokončených vět }\end{array}$} \\
\hline & $\begin{array}{c}\text { ISU v rámci } \\
\text { matematiky }\end{array}$ & $\begin{array}{c}\text { ISU v rámci } \\
\text { matematiky } \\
\text { a ostatních } \\
\text { předmětů }\end{array}$ \\
\hline $\begin{array}{c}\text { Závěr 3. } \\
\text { ročníku }\end{array}$ & 0,6 & \\
\hline $\begin{array}{c}\text { Závěr } 4 . \\
\text { ročníku }\end{array}$ & & 21,2 \\
\hline
\end{tabular}


- Sémantický diferenciál

Při analýze výsledků sémantického diferenciálu byly nejdřive vypočítány průměry ve všech faktorech. Z tabulky 3 je patrné, že celková výsledná hodnota diferenciálu:

a) klesá po výuce ISU v hodinách matematiky 3. ročníku (1. experiment);

b) klesá po výuce ISU v hodinách matematiky a ostatních předmětů ve 4 . ročníku (2. experiment).

Tabulka 3

Skóre postojů

\begin{tabular}{|c|c|}
\hline \multicolumn{2}{|c|}{ Sémantický diferenciál } \\
\hline Období měření & Skóre postojů \\
\hline Záŕí 2009 & 1005 \\
\hline Červen 2010 & 902 \\
\hline Červen 2011 & 857 \\
\hline
\end{tabular}

Na vstupu byla nejvyšší hodnota faktoru potence (síly) slovních úloh. To znamená, že žáci původně nepřikládali slovním úlohám význam ve smyslu přiměřenosti jasnosti zadání a propojení s ostatními předměty a chápali je spíše jako „nutné zlo“. Tento faktor vykazoval na výstupu zlepšení o celé čtyři body. Ve srovnání s faktorem hodnota a potence je na výstupu nejnižší faktor aktivity - žáci začali považovat slovní úlohy za dynamizující, úlohy nevyvolávaly zvýšené napětí. (Tabulka 3 a 4).

Tabulka 4

Faktory sémantického diferenciálu

\begin{tabular}{|c|c|c|c|c|c|c|c|c|c|}
\hline & \multicolumn{3}{|c|}{ Záŕí 2009} & \multicolumn{3}{|c|}{ Červen 2010} & \multicolumn{3}{|c|}{ Červen 2011} \\
\hline & hodnota & potence & aktivita & hodnota & potence & aktivita & hodnota & potence & aktivita \\
\hline Skóre & 274 & 383 & 348 & 295 & 316 & 291 & 294 & 289 & 274 \\
\hline Průměr & 11,9 & 16,65 & 15,13 & 12,83 & 13,74 & 12,65 & 12,78 & 12,57 & 11,91 \\
\hline Celkem & \multicolumn{3}{|c|}{1005} & \multicolumn{3}{|c|}{902} & \multicolumn{3}{|c|}{857} \\
\hline
\end{tabular}

Záznamový list sémantického diferenciálu jsme v červnu 2011 předložili kontrolním třídám A a B.

Skóre jednotlivých tř́id uvádíme v tabulce 5.

Tabulka 5

Vyhodnocení sémantického diferenciálu

\begin{tabular}{|c|c|c|c|}
\hline \multicolumn{4}{|c|}{ Vyhodnocení sémantického diferenciálu na výstupu } \\
\hline & Kontrolní skupina A & Kontrolní skupina B & Experimentální skupina C \\
\hline Skór & 1082 & 1023 & 857 \\
\hline
\end{tabular}


Podle vztahu

$$
|u|=\frac{U-\frac{n_{1} \cdot n_{2}}{2}}{\sqrt{\frac{n_{1} \cdot n_{2} \mathbf{6}_{1}+n_{2}+1}{12}}}
$$

jsme vypočítali významnost výsledků obou skupin. $\mathrm{n}_{1}$ je četnost jedné skupiny; $\mathrm{n}_{2}$ četnost druhé skupiny. Hodnotu testového kritéria jsme vypočítali podle vzorce:

$$
\begin{aligned}
& U=n_{1} \cdot n_{2}+\frac{n_{1} \cdot \mathbf{6}_{1}+1}{2}-\mathrm{R}_{1} \\
& U^{\prime}=n_{1} \cdot n_{2}+\frac{n_{2} \cdot \mathbf{6}_{2}+1}{2}-\mathrm{R}_{2}
\end{aligned}
$$

kde $\mathrm{R}_{1}$ je součet pořadí $\mathrm{v}$ jedné skupině $\mathrm{a} \mathrm{R}_{2}$ součet pořadí ve druhé skupině.

Výsledky jsme statisticky zpracovali pomocí u-testu (Chráska, 2007).

Výpočty normované náhodné veličiny $u$ uvádíme $\mathrm{v}$ tabulce. Vypočítanou hodnotu $u$ srovnáme s kritickou hodnotou $u_{0,0,5}=1,96$. Protože vypočítaná hodnota $u$ je větší než hodnota kritická, odmítáme nulovou hypotézu a prijímáme hypotézu alternativní. Mezi výsledky skupin jsou na hladině významnosti 0,05 statisticky významné rozdíly.

Tabulka 6

Náhodná normovaná veličina

\begin{tabular}{|l|l|}
\hline $\begin{array}{c}\text { Normovaná } \\
\text { náhodná } \\
\text { veličina }\end{array}$ & $/ \mathrm{u} /$ \\
\hline$/ \mathrm{u} / \mathrm{BC}$ & 5,74 \\
\hline$/ \mathrm{u} / \mathrm{AC}$ & 5,83 \\
\hline
\end{tabular}

\subsection{Závěry vyplývající z výzkumu}

Pro daný výběr byly učiněny následující závěry:

H I, H II: Zařazování integrovaných slovních úloh v rámci vyučovacích hodin matematiky i průřrezově v ostatních vyučovacích předmětech zlepšuje postoje žáků k řešení slovních úloh.

H III: Žáci kontrolní skupiny mají k řešení slovních úloh významně horší vztah než žáci skupiny experimentální.

Výsledky získané v šetření sémantickým diferenciálem byly potvrzeny také výsledky získanými pomocí metody nedokončených vět (Rakoušová, 2011). Na základě dosavadních výzkumných zjištění můžeme říci, že integrované slovní úlohy pozitivně ovlivňují postoje k řešení slovních úloh u daného vzorku žáků prvního stupně. 


\section{Závěr}

Žákovské postoje $\mathrm{k}$ řešení slovních úloh by mohlo zařazování integrovaných slovních úloh do vyučování žáků mladšího školního věku výrazně kladně ovlivnit. Na šetření, kterému je věnován tento př́spěvek, naváže rozsáhlejší experiment, ve kterém budou žáci pátého ročníku dále sledováni a výsledky budou porovnány s výsledky kontrolních trríd. Jak jsme ukázali v článku, metoda nedokončených vět a sémantického diferenciálu se jeví jako vhodná pro zjišt’ování postojů žáků 1. stupně základní školy.

\section{Poděkování}

Děkuji Doc. RNDr. Jarmile Novotné, CSc. za významné přispění ke zkvalitnění článku.

\section{Literatura}

Chráska, M. (2007). Metody pedagogického výzkumu. Základy kvantitativního výzkumu. Praha: Grada. Novotná, J. (2000). Analýza řešeni slovních úloh. Praha: PdF UK v Praze.

Novotná, J. (2010). Study of solving word problems in teaching of mathematics. From atomic analysis to the analysis of situactions. Saarbücken, Germany: LAP LAMBERT Academic Publishing.

Pelikán, J. (1998). Základy empirického výzkumu pedagogických jevư. Praha: Karolinum, 1998.

Rakoušová, A. (2011). Role uspořádání obsahu při rozvíjení postojů žáků primární školy. In N. Stehlíková \& L. Tejkalová (Eds.), Dva dny s didaktikou matematiky. Sborník přispěvkio. Praha: PdF UK v Praze. (v tisku)

Rakoušová, A. (2011). Vliv zařazování integrovaných slovních úloh do vyučování na postoje žáků 1. stupně základní školy k řešení integrovaných slovních úloh. In Š. Pěchoučková (Ed.), Sborník př́spěvků. Tvořivost v počátečním vyučováni matematiky - vědecká konference s mezinárodni účastí věnovaná matematickému vzdělávání v primární škole (pp. 195-199). Plzeň: Pedagogická fakulta Západočeské univerzity.

\section{Kontakt}

Mgr. Alena Rakoušová

Univerzita Karlova v Praze

Pedagogická fakulta, Katedra matematiky a didaktiky matematiky

M. D. Rettigové 4, 11639 Praha 1

e-mail: rakousova@plaminkova.cz

\section{Bibliografické údaje}

Rakoušová, A. (2011). Postoje žáků k řešení slovních úloh. In T. Janík, P. Knecht, \& S. Šebestová (Eds.), Smíšený design v pedagogickém výzkumu: Sborník přispěvků z 19. výročni konference České asociace pedagogického výzkumu (s. 439-445). Brno: Masarykova univerzita.

Dostupné z: http://www.ped.muni.cz/capv2011/sbornikprispevku/rakousova.pdf

doi: 10.5817/PdF.P210-CAPV-2012-51 